\title{
HOW PROBLEMS OF BUSINESS DEVELOP THEIR “NETWORK” AGAINST ORGANIZATIONAL STRUCTURE
}

\author{
Peter Harmath ${ }^{303}$ \\ https://doi.org/10.31410/itema.2018.856
}

\begin{abstract}
Structural solutions of organizations that fitted to the needs of external and internal environment as well to the business processes, usually means ability of leading successful enterprise. Different organizational design solutions are recommended for great variety of real situations depending on mission of company, the strategic goals, general and particular aims of management etc. In spite of the fact that all of those design parameters and properties can be well settled or designed for organization the enterprise can run into growing number of problems. Time to time the structural solutions need to be reconsidered. What about problems? Do they have their own structure of connectedness? Is it like an ever changing background? The aim of the study is to detect possible linkages between usual (most common problems) in management and organizational design solutions. The hypothesis is that those at first glance floating problems are also well structured (connected) especially when they appear with synergetic effects. According to the preliminary results, the theoretical background of contingency approach and methodology of Social Network Analysis can offer support to examine connectedness and linkages of organizational problems. Anyhow it is challenging, but very useful to learn more about "dark side" of organization, at least to learn how to ignore "devils power" in future steps of management.
\end{abstract}

Keywords: Organizational structure and design, business problems, contingency theory, Organizational Network Analysis

\section{INTRODUCTION}

$\mathrm{T}$ There are even more and more complains about the ever increasing challenges derived from changing complexity of business environment. Meantime the organizations are treating in more and more complex way. The pace of change has accelerated. Setting design solutions for organizational structure is becoming really complex task. There are a great number of variables to be considered in order to develop feasible and sustainable structural solutions for organizations. Contingency factors such as environment, strategy, technology, size, organizational climate, management style are depending on so many other factors, especially those that come from (at first glance always) from unknown directions. Their influence seems to be also unpredictable at first time.

The study will show and suggest a simple but applicable way of mapping the relations between factors that usually mean failure. Those connections of factors have to be considered and fitted in order to get a successful solution for organizational design. The approach is based on contingency theory analyzed with set of defined contingency factors according to Burton, Obel [1], [2]. The OrgCon 7.0 [1] software support includes the range of contingency factors: Management Style, - Organizational Climate, - Size/Ownership, - Environment, - Technology,

\footnotetext{
${ }^{303}$ University of Novi Sad, Faculty of Economics in Subotica, Segedinski put 9-11, 24000 Subotica, Serbia
} 
- Strategy. Out of "design properties" [1], [2], [3] there will be selected: - (structural) Form, Complexity/Differentiation, Formalization, and Centralization.

All of listed factors and properties have their wrong way of connectedness - so called, the misfits. This links of misfits will be examined as an initial or source (network) of failure. Social Network Analysis (SNA) supported with software's such as Pajek [4] or SocNetV [5] offered possibility for easy introspection. Most of the applied measures of SNA are part of Organizational Network Analysis (ONA) and can be applied in such cases.

\section{RESULTS}

The considered and selected list of misfits is shown in Table 1. These are the most typical types of "bad" links so the list is not complete. (This list cannot be completed at all.) Of course, the elements by themselves are regular potential for any specific excellent design solution. The harmful effects are derived from their mistaken connections. (The case sensitive bad selection of each factor or property is not considered in this study.) Instead, the basic contingency factors and design properties are listed with their common misfits - their inappropriate links that are unfavorable in any condition and any circumstances.

Table 1: Misfits between contingency factors [6]

\begin{tabular}{|l|l|}
\hline Climate misfits with & Technology \\
\hline Internal process climate & non routine technology \\
\hline Developmental climate & routine technology \\
\hline Climate misfits with & Strategy \\
\hline Internal process climate & analyzer with innovation strategy \\
\hline Internal process climate & prospector strategy \\
\hline Group climate & prospector strategy \\
\hline Developmental climate & defender strategy \\
\hline Climate misfits with & Leadership Style \\
\hline Group climate & Manager, Leader, and Entrepreneur \\
\hline Internal process climate & Leader and Entrepreneur \\
\hline Developmental climate & Manager and Entrepreneur \\
\hline Climate misfits with & Environment \\
\hline Group climate & high equivocality environment \\
\hline Internal process climate & high equivocality environment \\
\hline Developmental climate & low equivocality environment \\
\hline Developmental climate & low uncertainty environment \\
\hline Technology misfits with & Strategy \\
\hline Routine technology & prospector strategy \\
\hline Non routine technology & defender strategy \\
\hline Technology misfits with & Management style \\
\hline Non routine technology & Manager \\
\hline Technology misfits with & Environment \\
\hline Routine technology & high equivocality environment \\
\hline Non routine technology & low equivocality environment \\
\hline Environment misfits with & Strategy \\
\hline \multicolumn{2}{|c|}{} \\
\hline
\end{tabular}




\begin{tabular}{|l|l|}
\hline High equivocality environment & analyzer strategy \\
\hline Low equivocality environment & analyzer with innovation strategy \\
\hline Low equivocality environment & prospector strategy \\
\hline Low uncertainty environment & prospector strategy \\
\hline High equivocality environment & defender strategy \\
\hline
\end{tabular}

In addition some Contingency misfit propositions will be added to misfit links in order to widen the network of misfit connections. This list contains statements about contingency misfits with design properties.

Table 2. Source: Burton, Lauridsen, Obel. Fit and Misfits in the Multi-Dimensional Contingency Model: An Organizational Change Perspective, 2000.

\begin{tabular}{|c|c|c|c|}
\hline \multicolumn{4}{|c|}{ Leadership style misfit } \\
\hline A Manager & \multicolumn{3}{|c|}{$\begin{array}{l}\text { Low formalization, High decentralization, Divisional configuration, } \\
\text { Matrix configuration. }\end{array}$} \\
\hline A Leader & \multicolumn{3}{|c|}{$\begin{array}{l}\text { High formalization, Low decentralization, Simple configuration, } \\
\text { Functional configuration. }\end{array}$} \\
\hline Clim & \multicolumn{3}{|c|}{ is a misfit with: } \\
\hline Group climate & \multicolumn{3}{|c|}{$\begin{array}{l}\text { Functional configuration, High complexity, High centralization, } \\
\text { High formalization, }\end{array}$} \\
\hline $\begin{array}{l}\text { Developmental } \\
\text { climate : }\end{array}$ & \multicolumn{3}{|c|}{$\begin{array}{l}\text { Machine bureaucracy, Functional configuration, High complexity, High } \\
\text { centralization, and High formalization. }\end{array}$} \\
\hline $\begin{array}{l}\text { Internal process } \\
\text { climate }\end{array}$ & \multicolumn{3}{|c|}{$\begin{array}{l}\text { Simple configuration, Matrix configuration, Low complexity, Low } \\
\text { formalization. }\end{array}$} \\
\hline \multicolumn{4}{|c|}{\begin{tabular}{l|l} 
Rational goal climate & High formaliza \\
\end{tabular}} \\
\hline Size misfits & \multicolumn{3}{|c|}{ is a misfit with: } \\
\hline large organization & \multirow{2}{*}{\multicolumn{3}{|c|}{$\begin{array}{l}\text { Simple configuration, Low complexity } \\
\text { formalization. } \\
\text { High complexity, High formalization. }\end{array}$}} \\
\hline \begin{tabular}{|l|l} 
small organization & High complexity, High formalization. \\
\end{tabular} & & & \\
\hline \multicolumn{4}{|c|}{ Environment misfits } \\
\hline \multicolumn{4}{|c|}{ Equivocality - Low, Complexity - Low, Uncertainty - Low, } \\
\hline \multicolumn{3}{|c|}{ Equivocality - Low, Complexity - High, Uncertainty - Low, } & $\begin{array}{ll}\text { Matrix configuration, Low } \\
\text { formalization, } & \text { Low } \\
\text { complexity. } & \end{array}$ \\
\hline \multicolumn{3}{|c|}{$\begin{array}{l}\text { Equivocality - Low, Complexity - High, Uncertainty - } \\
\text { High }\end{array}$} & $\begin{array}{lr}\text { Simple configuration, } & \text { Low } \\
\text { complexity, } & \text { High } \\
\text { centralization. } & \\
\end{array}$ \\
\hline \multicolumn{2}{|c|}{$\begin{array}{l}\text { Equivocality - High, Complexity - Low, } \\
\text { Uncertainty - Low }\end{array}$} & \begin{tabular}{l|l}
$y-$ Low, & $\begin{array}{l}\text { Functional } \\
\text { formalization. }\end{array}$ \\
\end{tabular} & configuration, \\
\hline \multicolumn{4}{|c|}{ Equivocality - high, Complexity - Low, Uncertainty - High, } \\
\hline \multicolumn{4}{|c|}{$\begin{array}{l}\text { Equivocality - High, Complexity } \\
\text { - High, Uncertainty - High }\end{array}$} \\
\hline $\begin{array}{l}\text { Technology } \\
\text { misfits }\end{array}$ & \multicolumn{3}{|c|}{ is a misfit with: } \\
\hline \multicolumn{4}{|c|}{ 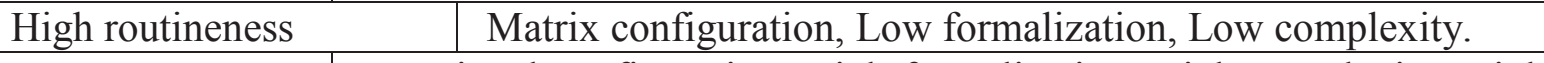 } \\
\hline Low routineness & \multicolumn{3}{|c|}{$\begin{array}{l}\text { Functional configuration, High formalization, High complexity, High } \\
\text { centralization. }\end{array}$} \\
\hline
\end{tabular}




\begin{tabular}{|l|l|}
\hline High divisibility & Matrix configuration, \\
\hline Low divisibility & Divisional configuration \\
\hline $\begin{array}{l}\text { STRATEGY } \\
\text { MISFITS }\end{array}$ & is a misfit with: \\
\hline $\begin{array}{l}\text { A prospector } \\
\text { strategy }\end{array}$ & $\begin{array}{l}\text { Functional configuration, High formalization, High complexity, High } \\
\text { centralization. }\end{array}$ \\
\hline An analyzer without innovation & Low formalization, Low complexity, Low centralization. \\
\hline An analyzer with innovation & Low complexity \\
\hline $\begin{array}{l}\text { A defender } \\
\text { strategy }\end{array}$ & $\begin{array}{l}\text { Matrix configuration, Low formalization, Low complexity, Low } \\
\text { centralization. }\end{array}$ \\
\hline
\end{tabular}

Table of misfit situations - connections Complement to Tables 6.1 and 6.3 in Burton and Obel (1998) [1]:

Picture 1. Mapped misfit linkage between considered elements

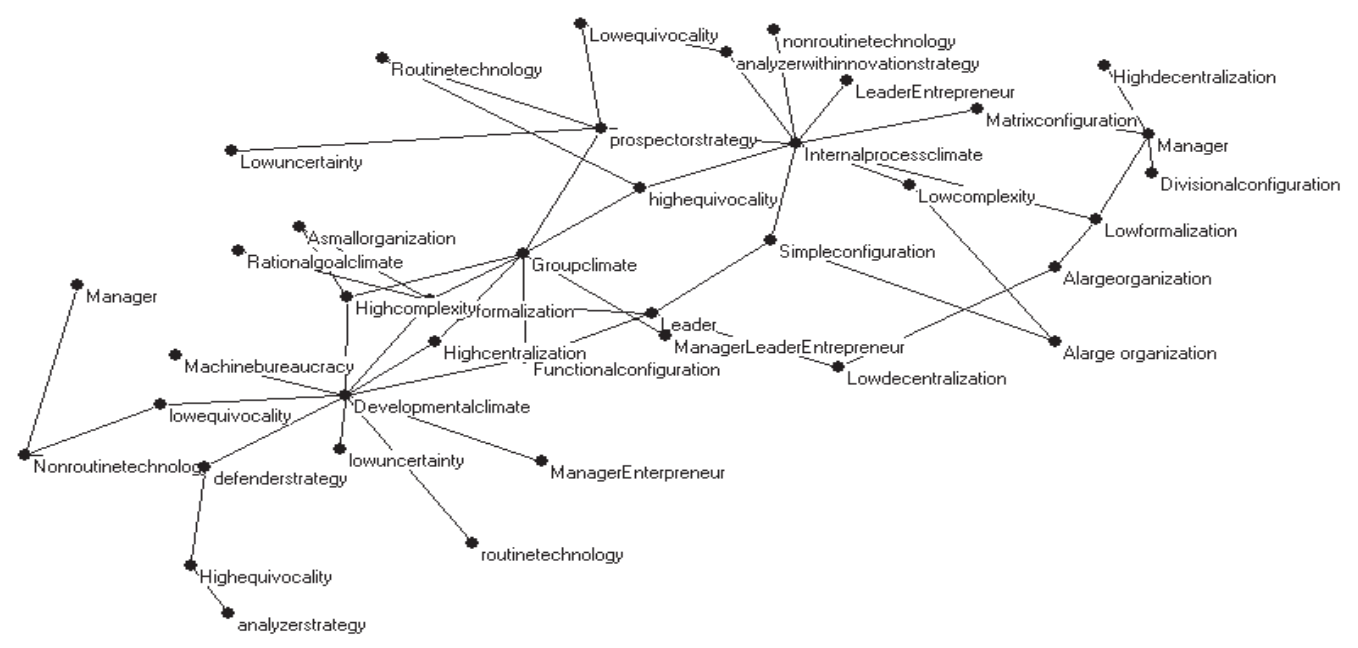

(Created with: Pajek [4])

Picture 1 is part of great set of possible positions (combinations of connections). The selected connections ("dangerous - devil's links" [7]) can be illustrated with e.g. black cells such as in Table 3 - Adjacency Matrix Plot. First encouraging fact is that the proportion of listed misfit situations between listed nodes is relatively low. $\left(\mathrm{DC}^{\prime} \mathrm{Mean}=0.069\right.$.) [5] That means there are plenty of other possible good links to build [8]. Of course, different solutions are depending on real situation and must be seriously considered and selected. (Not listed as misfit does not mean ideal solution!)

Adjacency Matrix Plot by SocNetV 2.3 software: Network name: contingency misfit factors with properties extended 3.net Actors: 39. This a plot of the network's adjacency matrix, a NxN matrix where each element $(i, j)$ is filled if there is an edge from actor $i$ to actor $j$, or not filled if no edge exists. (Existing edge of misfit) 
Table 3: Adjacency matrix plot (Source; Sotware: SocNetV 2.3)

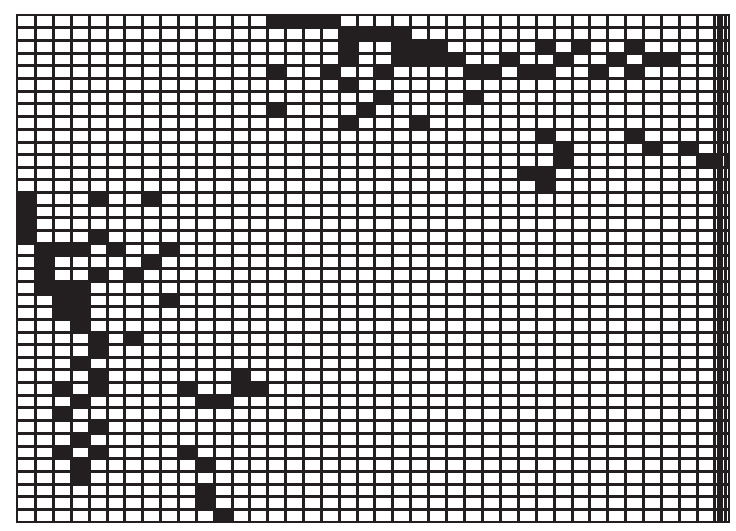

The other analyses performed, but without presented details in this paper were:

Clique Census (CLQs) report [5] The purpose of application of this group of measures was to detect which factor has the highest influential position, or power that can be considered with need for more sophisticated analyses. The following facts are quoted from SocNetV reports. "A clique is the largest subgroup of actors in the social network who are all directly connected to each other (maximal complete subgraph). SocNetV applies the Bron-Kerbosch algorithm to produce a census of all maximal cliques in the network and reports some useful statistics such as disaggregation by vertex and co-membership information.

Maximal Cliques found: 51 ." The power is relatively evenly distributed between nodes. There are no outstanding influential or prestige node. It is normal for the analyzed list of evenly performed misfits. This kind of analysis would be more interesting in particular case oriented studies.

Actor by clique analysis: Proportion of clique members adjacent Performed by $\mathrm{NxN}$ matrix. Not presented in this paper. It seems to be also only with case sensitive meaning.

Actor by actor analysis: Co-membership matrix. Performed by NxN matrix. Not presented in this paper.

Clustering Dendrogram (SVG) Not presented, Clique by clique analysis: Co-membership matrix.

\section{DISCUSSION}

Most of the influencing factors are characteristic for all branches of economic activity, [9] The selected misfits are showing bad organizational design solutions. Performed model of networked misfits suggest more sophisticated approach in setting organizational design fit.

The limitations of any kind of attempt to manage complex systems (such as organizations) are based in several conclusions about systems that function in changing conditions. Starting with cybernetics everyone agrees that "the state of a complex system is determined by a very large number of factors; the number of control actions is large and it is not possible to review all their combinations in an acceptable time in order to select the most favorable effect. The interplay of parts of the system and the environment takes place through so many channels that it is impossible to take into account in the management system. The characteristics and of the system and the environment are changed in time, according to laws that are never exactly known, and whose knowledge is necessary for management. ... In order to calculate optimal management, time is needed, so much longer if a more complex system is managed, ...”[10] 
Illustrations show the model that is composed on the principles of contingency misfit and represents a typical example of a simplified network of badly connected factors and properties of organization. In order to better understanding of an organization model is designed to process relatively small number of factors and low flows of information (connectedness) to be able to quickly control actions calculated for short time intervals. Of course, for longer periods bigger models should be developed with large amounts of data for setting organization design solutions. Usually "Higher ranking models work even slower, but they produce far-reaching management.... Ranks (the links - added author) interact with one another and form the controlling actions" [1]

The presented model shows the sources of dangerous connections as possible line of synergetic effects; possibility of growing malfunctions of organization because of being lined up in order of misfit situations. Social Network Analysis (SNA) tools give strong base for Organizational Network Analysis (ONA). Considered measures of SNA or ONA as "measures for individual actors" [11],112] the nodes, are taken from the listed contingency factors and organizational design properties. Together with typical "measures for analyses of entire network" [11],112] the usability of model is depending on case sensitive data entrance. (Specifically defined solutions to be tested - analyzed.) The plot matrix shows the mistaken solutions or misfit positions. It can be perceived as well as the "devil's area". It has to be avoided while setting organizational design. The given example of linkages between some contingency factors and organizational design properties proves potential for this kind of presentation and helps comprehension of hidden sources of failures in organizational design solutions.

\section{CONCLUSION}

It is obvious that maintaining the balance between contingency, - situational factors and organizational design properties are limited with the complexity of phenomenon. This fact explains why business organizations cannot be fully under stained and why business results will always be below objectively possible.

As a matter of fact, the factors and properties can be ranked into network against health of organization. The failure may result from accumulated negative impacts of inadequately linked propositions. Knowing about basic inconsistencies there is a possibility to avoid failures generated by misfits. Network of bad connections the misfit's network or the "devil's network" potentially may exist in every organization. It is up to skilled leaders, managers, organizers to avoid such connections. Some of the typical measures for individual actors can be applied for nodes with the notion that the weightings of their impact can vary widely, depending on the branch and the objective conditions in which the effects of the influence factors are manifested.

Misfit situations always have to be avoided. It is very useful to have mapped linkages of misfit situations in order to get transparency of real situation. Every real situation differs. It is very important to notice that none of the nodes is a misfit by itself. The harmful effects derive from the mistaken direction of connections between elements - design solutions. Those mistaken connections - links are developing the malfunctioning of organization. The introduced model is performing mapped links of limited number of misfit situations. The real situation can produce plenty of other combinations of linkages that are also unacceptable. "... however much we improve it, it remains an imperfect expert system that requires a skilled and experienced user to apply it in a reasonable fashion ..." (p. 34). [1] 
Hostile or "devil's areas" can be multiplied if organizer ignores the possibly longer linkages. The effects of synergy can be illustrated with clustering effects in this case as the set of mistaken choice of organizational properties.

\section{REFERENCES}

[1] Burton Richard M, Obel Borge (1998), Strategic Organizational Diagnosis and Design: Developing Theory for Application, Kluwer Academic Publishers, second edition

[2] Burton, Richard M. Obel, Børge (2004), Strategic Organizational Diagnosis and Design, The Dynamics of Fit, 3rd edition, Springer

[3] Burton, Richard M. DeSanctis Gerardine, Obel Børge, (2006), Organizational Design: A Step-By-Step Approach, Cambridge University Press, New York.

[4] Software: Pajek 2.04, Vladimir Batagelj and Andrej Mrvar, Free for noncommercial use. http://pajek.imfm.si/

[5] Software SocNetV 2.3, (2017), by Dimitris V. Kalamaras, http//socnetv.org

[6] EcoMerc, https://orgcon.ecomerc.com/help/9/introduction/science\%20base/fit/strategic_misfits.htm 1 (accessed 10.10.2018)

[7] Barabási Albert László, (2010), Villanások - a jövő kiszámitható, (The hidden pattern behind everything we do). Nyitott konyvmuhely, Budapest.

[8] Cross Rob, Parker Andrew (2004) The Hidden Power of Social Networks, Understanding How Work Really Gets Done in Organizations, Harvard Business Press, Boston.

[9] Ahmetagić E., Harmath P. (2009), Projektovanje organizacije, Ekonomski fakultet, Subotica

[10] A. J. Lerner (1975), Principles of Cybernetics, ICS Beograd, p. 310-313.

[11] Borgatti, S.P., Everett, M.G. and Johnson, J.C., (2013). Analyzing social networks. SAGE Publications Limited.

[12] Brass, D.J. (1995),"A social network perspective on human resources management." Research in Personnel and Human Resources Management, 13, pp 39-79. 